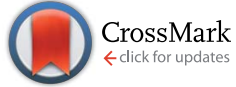

Cite this: J. Mater. Chem. B, 2015, 3, 2624

Received 20th December 2014 Accepted 30th January 2015

DOI: $10.1039 / c 4 t b 02104 \mathrm{e}$

www.rsc.org/MaterialsB

\section{Directional Plk1 inhibition-driven cell cycle interruption using amphiphilic thin-coated peptide-lanthanide upconversion nanomaterials as in vivo tumor suppressors $\uparrow$}

\author{
Chi-Fai Chan, ${ }^{a}$ Rongfeng Lan, ${ }^{a}$ Ming-Kiu Tsang, ${ }^{e}$ Di Zhou, ${ }^{d}$ Sam Lear, ${ }^{c}$ \\ Wai-Lun Chan, ${ }^{a}$ Steven L. Cobb, ${ }^{\star c}$ Wai-Kwok Wong, ${ }^{a}$ Jianhua Hao, ${ }^{e}$ \\ Wing-Tak Wong ${ }^{\star b g}$ and Ka-Leung Wong*af
}

Polo-like kinase 1 (Plk1) is a major serine/threonine protein kinase which regulates key mitotic events such as centrosome duplication, spindle assembly and chromosome separation. Overexpression and aberrant activities of Plk1 can be detected in different types of cancer. Given that the unique polo box domain (PBD) pocket provides an excellent drug target for Plk1 binding and inhibition, we have rationally designed multifunctional lanthanide-doped upconversion nanomaterials. $\mathrm{NaGdF}_{4}: \mathrm{Yb}^{3+}, \mathrm{Er}^{3+}\left(\mathrm{NaGdF}_{4}\right)$ and $\mathrm{BaGdF}_{5}: \mathrm{Yb}^{3+}, \mathrm{Er}^{3+}\left(\mathrm{BaGdF}_{5}\right)$ nanoparticles of two different sizes $(60 \mathrm{~nm}$ and $10 \mathrm{~nm}$, respectively) have been thin-coated with Plk1 specific peptides $\left(-\mathrm{P}_{1}=\right.$ PLHSpT, $-\mathrm{P}_{2}=$ PLHSD, and $\left.-\mathrm{P}_{3}=\mathrm{GGPLHSpT}\right)$ to prepare novel nanomaterials. Comparative studies on cellular uptake, anti-cancer activity and imaging properties were then carried out. The experimental data obtained support our original hypothesis that the designed nanomaterials can successfully deliver Plk1 specific peptides into cancer cells causing Plk1 inhibition while simultaneously allowing direct NIR imaging and monitoring. Among the $\mathrm{NaGdF}_{4}-\mathrm{P}_{n}$ and $\mathrm{BaGdF}_{5}-\mathrm{P}_{n}$ nanoparticle series prepared in this study, $\mathrm{NaGdF}_{4}-\mathrm{P}_{1}$ emerged as the best candidate for Plk1 binding and imaging. $\mathrm{NaGdF}_{4}-\mathrm{P}_{1}$ can effectively exert cell cycle $\mathrm{G} 2 / \mathrm{M}$ arrest and thus selective tumor inhibition both in vitro and in vivo and as such it offers a potentially interesting system for the development of new cancer therapies.

\section{Introduction}

The human polo-like kinase family (Plk1-5) is responsible for a wide variety of cell regulatory activities such as the DNA damage response, bipolar spindle formation, mitotic entry as well as cytokinesis. ${ }^{1-5}$ However, the actual role of Plk1 in carcinogenesis

\footnotetext{
${ }^{a}$ Department of Chemistry, Hong Kong Baptist University, Kowloon Tong, Hong Kong. E-mail: klwong@hkbu.edu.hk

${ }^{b}$ Department of Applied Biological and Chemical Technology, The Hong Kong Polytechnic University, Hung Hom, Hong Kong. E-mail: bcwtwong@polyu.edu.hk 'Department of Chemistry, Durham University, Durham, DH1 3LE, UK. E-mail: s.l. cobb@durham.ac.uk

${ }^{d}$ School of Chemistry and Material Engineering Jiangsu, Key Laboratory of Advanced Functional Materials, Changshu Institute of Technology, Changshu, China

${ }^{e}$ Department of Applied Physics, The Hong Kong Polytechnic University, Hung Hom, Hong Kong

${ }^{f}$ Changshu Research Institute of Hong Kong Baptist University, Changshu Economic and Technological Development Zone, Jiangsu 215500, China

${ }^{8}$ State Key Laboratory for Chirosciences from The Ministry of Science and Technology of the People's Republic of China, The Hong Kong Polytechnic University, Hung Hom, Hong Kong
}

$\dagger$ Electronic supplementary information (ESI) available. See DOI: 10.1039/c4tb02104e is still yet to be fully elucidated. Some pre-clinical evidence suggests that overexpression of Plk1 is linked to an increased survival rate of cells, ${ }^{6}$ and this is supported by the fact that Plk1 is normally highly expressed in actively proliferating tissue. ${ }^{7}$ Strategic inactivation of Plk1 results in cell cycle arrest and subsequently apoptosis, thus Plk1 has emerged as a favorable therapeutic target for cancer treatment. ${ }^{8}$

Within Plk1, there are two distinct domains-an aminoterminal kinase domain and a unique carboxyl terminal polo box domain (PBD). Several organic small molecules which can inhibit the Plk1 kinase domain and the PBD have been identified. Molecules such as BI2536, CBB2001 and MLN0905 target the kinase domain of Plk1 causing inhibition as well as pronounced dose-limiting toxicity (DLT), ${ }^{9-11}$ however unspecific activities and unwanted side-effects have really limited the further development of Plk1 kinase domain targeting molecules. On the other hand, peptides and their analogues that can bind to the PBD present a novel and promising avenue for Plk1 targeting and inhibition. ${ }^{\mathbf{1 2 , 1 3}}$ Peptides can be employed as tailormade inhibitors and potential drugs but there are issues in working with this class of biological molecules. Peptides often display physical and chemical instabilities, ${ }^{\mathbf{1 4}}$ poor cellular 
uptake, and localization issues. ${ }^{15}$ Real-time assessments, including MTT, in vitro imaging and tumor inhibition, are also crucial elements in cancer prognosis and treatment. Conventionally, for imaging purposes complex methods of analysis such as immunostaining of Plk1 using antibodies or fusion fluorescent proteins have been employed..$^{16,17}$ Recently, E. K. Ryu et al. demonstrated that a Plk1-specific peptide (PLHSpT) conjugated with the $\alpha_{\mathrm{v}} \beta_{3}$ integrin receptor inhibitor peptide (RGD) and a radioligand can achieve the much sought-after theranostic effect. ${ }^{14}$ However, this is a rather indirect method of analysis as it only tests cancer cells which involves multiple steps to interrupt the cell cycle, inhibit the tumor size, and diagnose the cancer tissues with PET. Most recently, we have reported a porphyrin conjugated to a Plk1-specific peptide (e.g. PLHSpT) as a multi-modal bio-probe, with the molecular system serving as the vector. ${ }^{18}$ Its overall tumor growth inhibition efficiency through the singlet oxygen generation has, indeed, still room for further improvement.

In the present study we have prepared lanthanide-doped upconversion nanoparticles (UCNPs) which can act as delivery vehicles for Plk1-specific peptides. The nano-particle-peptide conjugates were shown to inhibit Plk1 activity, while cell-cycle arrest and visualization can also be achieved simultaneously. Owing to the excellent photo-physical properties of lanthanide ions, the dopant ions (ytterbium/erbium) can be excited and emit in the near-infrared (NIR) region. The nano-systems developed also offer additional benefits for bio-imaging such as improved light penetration depth, lower cytotoxicity and, above all, elimination of autofluorescence due to the long emission lifetime ( $\mu$ s to $\mathrm{ms}$ ) of lanthanides compared with that of organic biomarkers. ${ }^{19-28}$ By conjugating the PBD binding peptide onto UCNPs, the cellular uptake problem of the individual peptides can also be addressed because the resulting organic-inorganic nanomaterial is highly biocompatible,${ }^{29,30}$ and the peptides are protected from enzymatic degradation. ${ }^{31}$ Although, in the case of cyclin D, the inhibitory effects of our previously established UCNPs $\left(\mathrm{NaGdF}_{4}: \mathrm{Yb}^{3+}, \mathrm{Er}^{3+}\right)$ conjugated with cyclin D-specific peptides were not as satisfactory as expected, ${ }^{32}$ we have rationalized that this could be ascribed to unwanted cross-binding among various cyclins and their cyclin-dependent kinases (CDKs), ${ }^{33}$ in addition, the in vitro emission signal was also quenched after bio-conjugation when compared to the unmodified $\mathrm{NaGdF}_{4}: \mathrm{Yb}^{3+}, \mathrm{Er}^{3+}$. With these factors in mind, we have now developed a new type of novel peptide-functionalized UCNP which can achieve termination and visualization of cancer cells concurrently through binding and inhibition of Plk1.

Herein, we report the synthesis of eight UCNPs, using two solid systems of different sizes-60 nm NaGdF $4: \mathrm{Yb}^{3+}, \mathrm{Er}^{3+}$ $\left(\mathbf{N a G d F}_{4}\right)$ and $10 \mathrm{~nm} \mathrm{BaGdF}{ }_{5}: \mathrm{Yb}^{3+}, \mathrm{Er}^{3+}\left(\mathbf{B a G d F}_{5}\right)$. These two types of UCNPs are square, doped with $\mathrm{Yb}^{3+}$ and $\mathrm{Er}^{3+}$ at molar ratio 18: 2 and coated with polyethyleneimine (PEI), PLHSpT $\left(\mathbf{P}_{\mathbf{1}}\right),{ }^{\mathbf{1 3 , 1 4}}$ PLHSD $\left(\mathbf{P}_{2}\right)$ and GGPLHSpT $\left(\mathbf{P}_{\mathbf{3}}\right)$ respectively (Fig. 1). All three peptides have already shown strong binding with PBD in Plk1. ${ }^{13} \mathbf{P}_{3}$, which contained an additional Gly-Gly motif, was used primarily to check whether any significant impact on the binding affinity between the peptide (i.e. PLHSpT) and Plk1, as well as the anti-tumor activity was observed when the linking

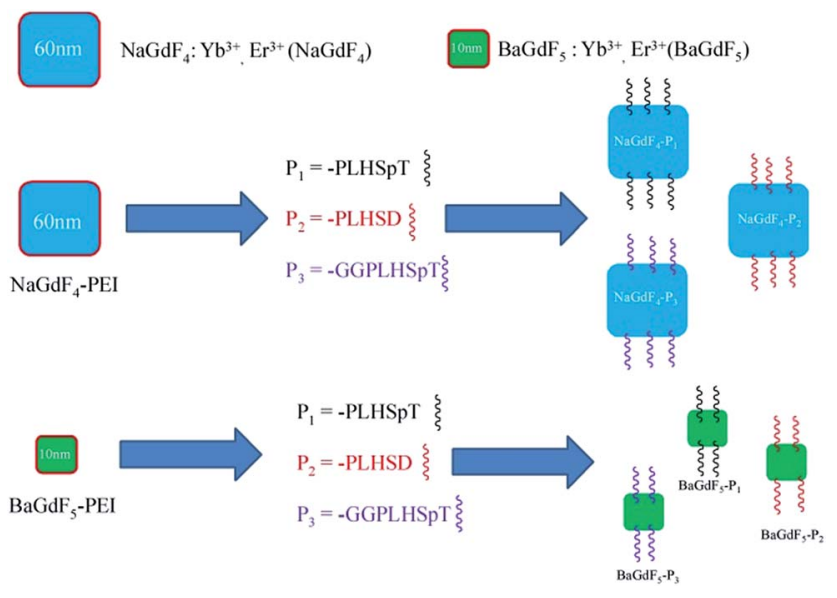

Fig. 1 Schematic diagram of conjugating Plk1 specific peptides onto $\mathrm{NaGdF}_{4}$ and $\mathrm{BaGdF}_{5}$.

distance between the UNCPs and the peptides was increased in length and flexibility. Comprehensive in situ (photophysical properties, protein pull down assay), in vitro (emission spectra, imaging, co-staining with GFP-Plk1, ICP-MS, cellular toxicity) and in vivo studies (imaging and solid tumor inhibition) in both cancer and normal cell lines have been conducted and the data are presented. Experimental results revealed that our $60 \mathrm{~nm}$ UNCPs have a better performance than the $10 \mathrm{~nm}$ UCNPs in terms of uptake efficiency and imaging quantity. In particular for $\mathbf{N a G d F}_{\mathbf{4}}-\mathbf{P}_{\mathbf{1}}$ coated with the $\mathbf{P}_{\mathbf{1}}$ peptide; control experiments have illustrated that $\mathbf{N a G d F}_{\mathbf{4}}-\mathbf{P}_{\mathbf{1}}$ is selective in its mode of action and it was demonstrated to have no anti-growth effect in normal cells.

\section{Results and discussion}

Through conjugation to various inorganic molecules such as nanoparticles, peptides can be effectively shielded from enzymatic degradation. In addition peptide coated UNCPs can be excited at $980 \mathrm{~nm}$ enabling their real-time imaging. In this study, we intended to exploit both these aforementioned properties coupled with Plk1 targeting to design and prepare nanosystems capable of simultaneous Plk1 inactivation and real time imaging, something that is not currently easily achievable. Two sets of UNCPs of different sizes have been conjugated with three kinds of Plk1 specific peptides and photophysical properties, cellular uptake efficiency, in vitro imaging and selectivity for Plk1 of these systems have been evaluated. The UCNPs have been characterized and verified by a series of experiments including spectroscopic measurements, microscopic analyses and competitive assays through protein binding and western blotting. In addition to investigating the selection of Plk1 specific peptides and different UCNPs, we also wished to probe the effects of the size and shape of UCNPs themselves. Thus we used $60 \mathrm{~nm}$ and $10 \mathrm{~nm}$ UCNPs as both of them have a similar crystal lattice and they are square in shape. Through this comprehensive study, we aimed to satisfy our hypothesis that Plk1 specific coated nanomaterials can act as promising systems in the future development of multimodal anti-cancer upconversion nano-drugs. 


\subsection{Synthesis and characterization of nanoparticles} conjugated with Plk1 $\left(P_{n}\right)$ specific peptides

The surface groups of our $\mathbf{N a G d F}_{\mathbf{4}}$ and $\mathbf{B a G d F}_{5}$ were examined by FTIR. The corresponding IR transmission spectra of aminefunctionalized $\mathbf{N a G d F}_{4}$ and $\mathbf{B a G d F}_{5}$ are shown in Fig. S1. $\dagger$ The broad absorption band centered at $3459 \mathrm{~cm}^{-1}$ is due to the $\mathrm{O}-\mathrm{H} / \mathrm{N}-\mathrm{H}$ stretching vibration. The IR absorption peaks at 1637 and $1436 \mathrm{~cm}^{-1}$ are attributable to the $\mathrm{N}-\mathrm{H}$ bending of the amino group $\left(\mathrm{NH}_{2}\right)$ and the $\mathrm{C}-\mathrm{N}$ bond stretching vibration. Therefore, the IR transmission spectrum fully supports the capping of poly(ethyleneimine) (PEI) on the surfaces of $\mathbf{N a G d F}_{4}$ and $\mathbf{B a G d F}_{5}$. The amine-functionalized $\mathbf{N a G d F}_{\mathbf{4}}$ and $\mathbf{B a G d F}_{5}$ were then modified into amide-functionalized $\mathbf{N a G d F}_{4}$-ene and BaGdF $_{5}$-ene. The conversion of amine to amide was verified by the IR spectrum in Fig. S1(b). $\dagger$ The overall spectrum is similar to Fig. S1(a). $\dagger$ In fact, the absorption peaks at $1648 \mathrm{~cm}^{-1}$ newly appear under the stretching vibration of the $\mathrm{C}=\mathrm{O}$ bond. ${ }^{34}$ Fig. S1(c) $\dagger$ shows the IR spectrum recorded after addition of the target specific peptide $\mathbf{P}_{\boldsymbol{n}}$ on the surfaces of $\mathbf{N a G d F}_{\mathbf{4}}$ and BaGdF $_{5}$. The small absorption peaks around 3022 to $3417 \mathrm{~cm}^{-1}$ represent the $\mathrm{N}-\mathrm{H}$ bond stretching while the broad peak at 3307 $\mathrm{cm}^{-1}$ stands for carboxylic acid. Hence, we had confirmed the successful coating of target specific peptide $\mathbf{P}_{\boldsymbol{n}}$ onto our $\mathbf{N a G d F}_{\mathbf{4}}$ and $\mathbf{B a G d F}_{5}$.
The shape and morphology of $\mathbf{N a G d F}_{4}$ or $\mathbf{B a G d F}_{5}$ and peptide coated $\mathbf{N a G d F}_{4}-\mathbf{P}_{n}$ or $\mathbf{B a G d F}_{5}-\mathbf{P}_{n}$, on the other hand, were investigated by TEM. In Fig. 2a and b, the morphology of $\mathbf{N a G d F}_{\mathbf{4}}$ and $\mathbf{B a G d F}_{5}$ was square in shape which corresponds to the cubic phase of $\mathbf{N a G d F}_{\mathbf{4}}$ and $\mathbf{B a G d F}_{5}$. This observation is similar to the previously reported synthesis of the cubic phase $\mathbf{N a G d F}_{\mathbf{4}}$ (ref. 30) and $\mathbf{B a G d F}_{\mathbf{5}}$ (ref. 22) which was verified by the SAED pattern of $\mathbf{N a G d F}_{4}$ and $\mathbf{B a G d F}_{5}$ as shown in Fig. S2. $\dagger$ From the high resolution TEM (HRTEM), a thin layer is observed (as indicated by red arrows) and the size distribution in TEM images reveals also that the overall sizes of Plk1 specific peptide coated $\mathbf{N a G d F}_{4}-\mathbf{P}_{\boldsymbol{n}}$ and $\mathbf{B a G d F}_{5}-\mathbf{P}_{\boldsymbol{n}}$ increase by 1-2 nm compared with the bare $\mathbf{N a G d F}$ and $\mathbf{B a G d F}_{5}$, thereby justifying the conjugation of $\mathbf{N a G d F}_{4}$ and $\mathbf{B a G d F}_{5}$ with peptide $\mathbf{P}_{\boldsymbol{n}}$. As demonstrated by the dynamic light scattering analysis, the size of the nanomaterials is also increased by 1-3 $\mathrm{nm}$ after the peptide conjugation (Fig. $\mathrm{S} 5 \dagger$ ). Besides, the surface charges of $\mathbf{N a G d F}_{4}$ and $\mathbf{B a G d F}_{5}$ should be different before and after the peptide conjugation. In Fig. 3, there is clearly a drop of zeta potential which again qualifies the successful peptide conjugation onto our nanomaterials.

The phase composition of $\mathbf{N a G d F}_{4}$ or $\mathbf{B a G d F}_{5}$ and peptide coated $\mathbf{N a G d F}_{4}-\mathbf{P}_{\boldsymbol{n}}$ or $\mathbf{B a G d F}_{5}-\mathbf{P}_{\boldsymbol{n}}$ was revealed by powder X-ray diffraction (XRD). In Fig. 2e and f, the $\mathbf{N a G d F}_{\mathbf{4}}$ and $\mathbf{B a G d F}_{5}$ were indexed to the standard cubic phase $\mathbf{N a G d F}_{\mathbf{4}}$ (JSPDF\#27-0697)
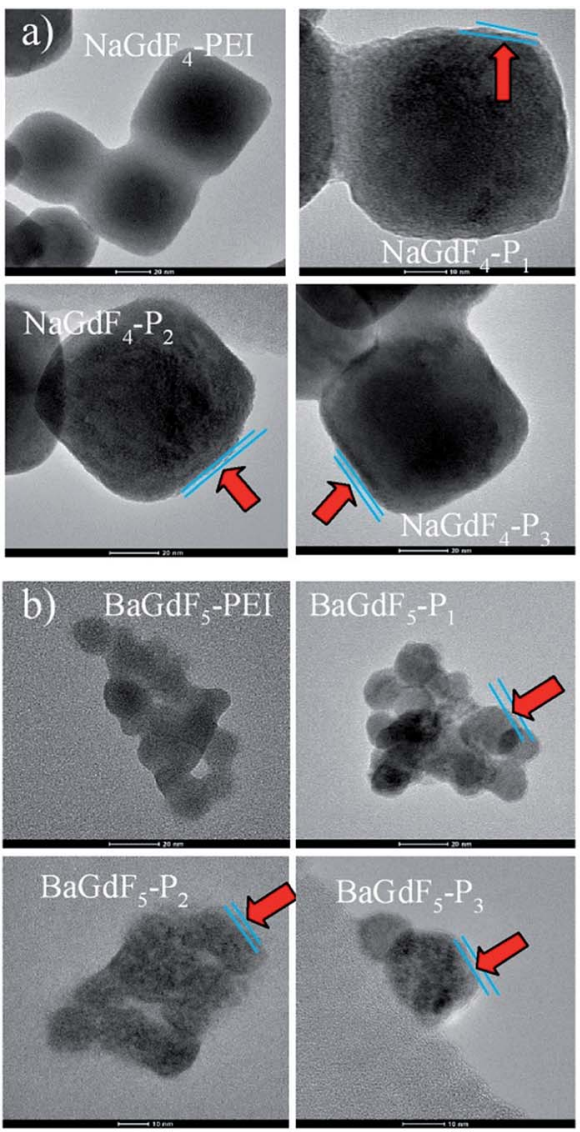

$\mathrm{BaGdF}_{-}-\mathrm{P}_{3}$

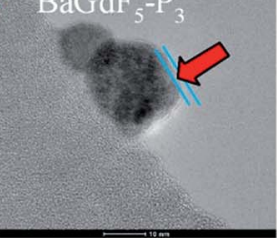

c)

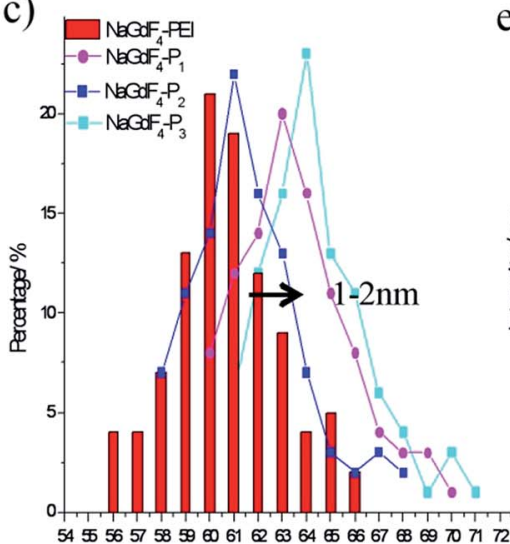

d)

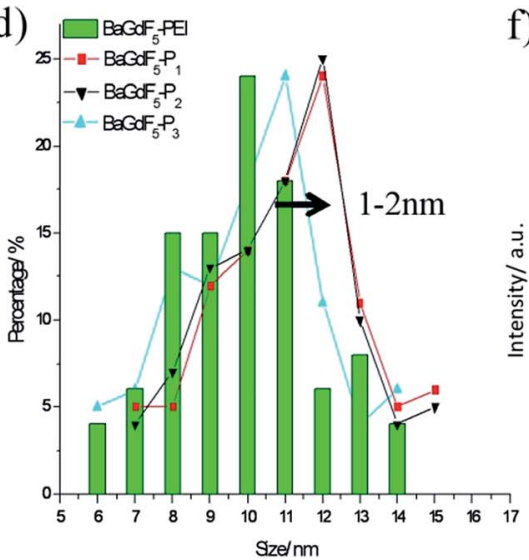

f)
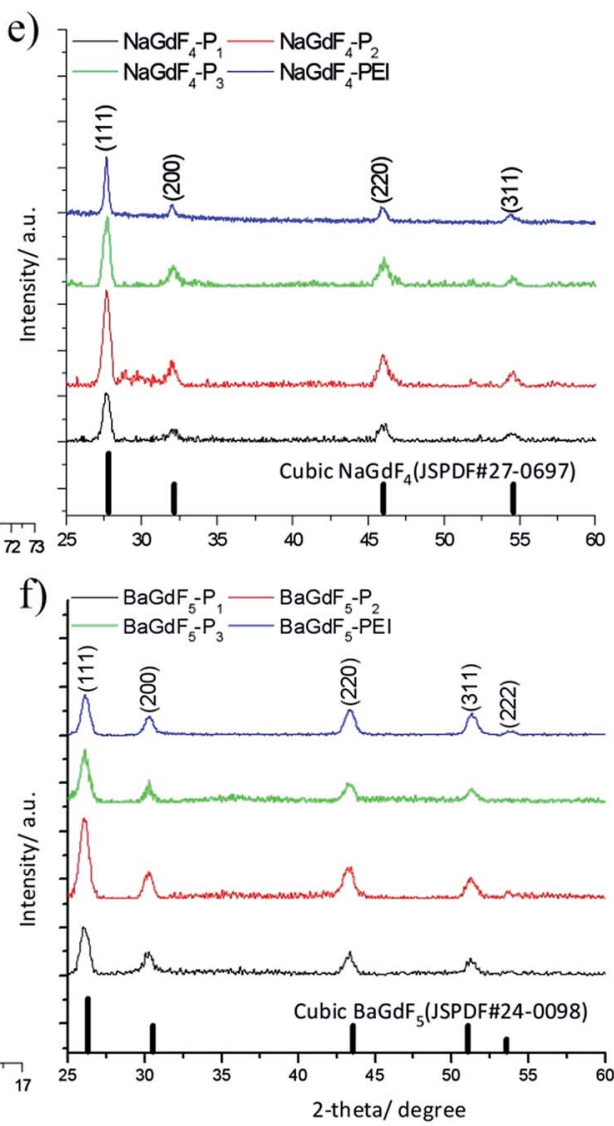

Fig. 2 Surface characterization by ( $a$ and b) TEM analysis; (c and d) size distribution and (e and f) XRD pattern analysis. 


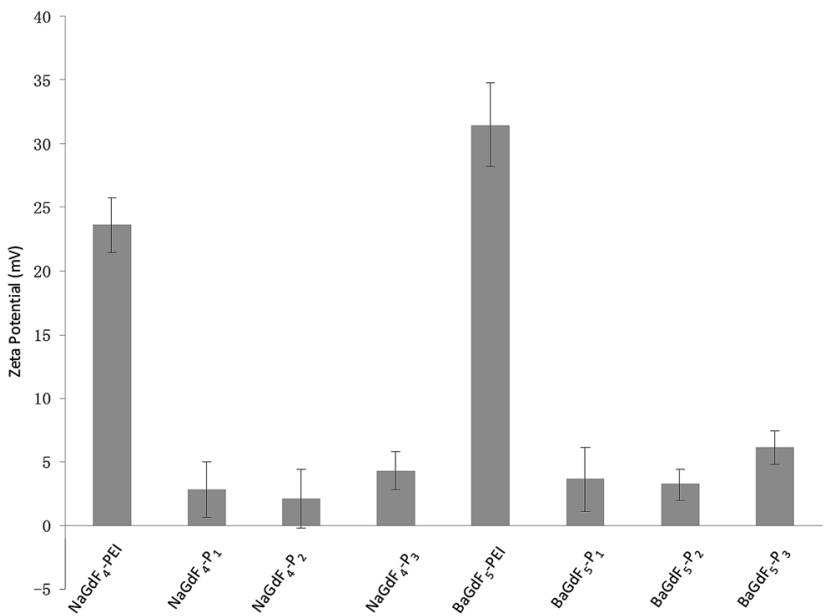

Fig. 3 Peptide conjugation leads to a drop of zeta potential since peptides are relatively more negative compared with the $\mathrm{PEI}$ on $\mathrm{NaGdF}_{4}$ or $\mathrm{BaGdF}_{5}$.

and $\mathbf{B a G d F}_{\mathbf{5}}$ (JSPDF\#24-0098) respectively. The diffraction peaks agree well with the standard pattern, with the matching results indicating that our $\mathbf{N a G d F}$ and $\mathbf{B a G d F}$ are present in the pure cubic phase with no other phase impurities. After the coating of Plk1 specific peptides on the surface of $\mathbf{N a G d F}_{4}-\mathbf{P}_{\boldsymbol{n}}$ or $\mathbf{B a G d F}_{5}-$ $\mathbf{P}_{\boldsymbol{n}}$, the XRD patterns show no changes in the 2-theta angles and this implies that the coating of peptides did not induce changes in the crystal structures of both $\mathbf{N a G d F}_{4}$ and $\mathbf{B a G d F}_{5}$. Also, this observation was consistent with the non-crystalline nature of peptides.

\subsection{Photophysical properties of upconversion nanoparticles}

In $\mathrm{Yb}^{3+}$ and $\mathrm{Er}^{3+}$ co-doped nanoparticles, under $980 \mathrm{~nm}$ laser diode excitation, $\mathrm{Yb}^{3+}$ ions possessing a large absorption crosssection, much longer excited state lifetime and the energy $\left({ }^{2} \mathrm{~F}_{5 / 2} \rightarrow{ }^{2} \mathrm{~F}_{7 / 2}\right)$ well resonant with higher-energy states of other lanthanide ions can transfer energy continuously and efficiently to $\mathrm{Er}^{3+}$ ions, leading to bright upconversion luminescence in the visible region. Fig. 4 shows the emission spectra of the peptide coated $\mathbf{N a G d F}_{4}$ and $\mathbf{B a G d F}_{5}$ (NPs), as well as the spectra of all the coated NPs indicating the same structures. The three emission peaks at $521 \mathrm{~nm}, 541 \mathrm{~nm}$, and $650 \mathrm{~nm}$ arise from ${ }^{2} \mathrm{H}_{11 / 2} \rightarrow{ }^{4} \mathrm{I}_{15 / 2}$, ${ }^{4} \mathrm{~S}_{3 / 2} \rightarrow{ }^{4} \mathrm{I}_{15 / 2}$, and ${ }^{4} \mathrm{~F}_{9 / 2} \rightarrow{ }^{4} \mathrm{I}_{15 / 2}$ transitions respectively, which are ascribed to the two-photon upconversion process under 980 nm excitation with $340 \mathrm{~mW}$ and commonly present in nanomaterials doped with $\mathrm{Yb}^{3+}$ and $\mathrm{Er}^{3+}$ ions. The nearby peaks originated from transitions between other Stark levels of the corresponding excited energy levels and the ground state. In order to understand the upconversion mechanism well, we measured the decay time curves for the peptide coated UCNPs. The insets of Fig. $4 \mathrm{a}$ and $\mathrm{b}$ display the luminescence decay curves of the ${ }^{4} \mathrm{~S}_{3 / 2} \rightarrow{ }^{4} \mathrm{I}_{15 / 2}$ transition of $\mathrm{Er}^{3+}$ ions in $\mathrm{NaGdF}_{4}-\mathbf{P}_{\boldsymbol{n}}$ and $\mathbf{B a G d F}_{5}-\mathbf{P}_{\boldsymbol{n}}$. Each of the down edges of the decay curves can be fitted well into a single exponential function $I(t)=I_{0} \exp (-t / \tau)$, where $I_{0}$ is the initial emission intensity at $t=0$, and $\tau$ is the decay time. The lifetime of the $541 \mathrm{~nm}$ emission peak is $\sim 30 \mu \mathrm{s}$. Moreover, all the decay curves consist of rising edges, indicating that the population of ${ }^{4} \mathrm{~S}_{3 / 2}$ originates from the energy transfer of the sensitizer $\mathrm{Yb}^{3+}$ ions. The upper level ${ }^{4} \mathrm{~F}_{7 / 2}$ was populated by two-step upconversion energy transfer of $\mathrm{Yb}^{3+}$ ions and then nonradiatively relaxed to ${ }^{4} \mathrm{~S}_{3 / 2}$, which resulted in the $541 \mathrm{~nm}$ emission. Thus the population of the ${ }^{4} \mathrm{~S}_{3 / 2}$ level is closely related to the phonon state density and the emission would be sensitive to temperature. From Fig. 4a, the nanoparticles of $\mathbf{N a G d F}_{\mathbf{4}}$ coated with different peptides show remarkably different emission intensities, thereby implying the obvious influence of the surface coating on the upconversion properties of the nanoparticles. In short, the peptide coated nanoparticle emitting long lifetime bright visible light under near infrared

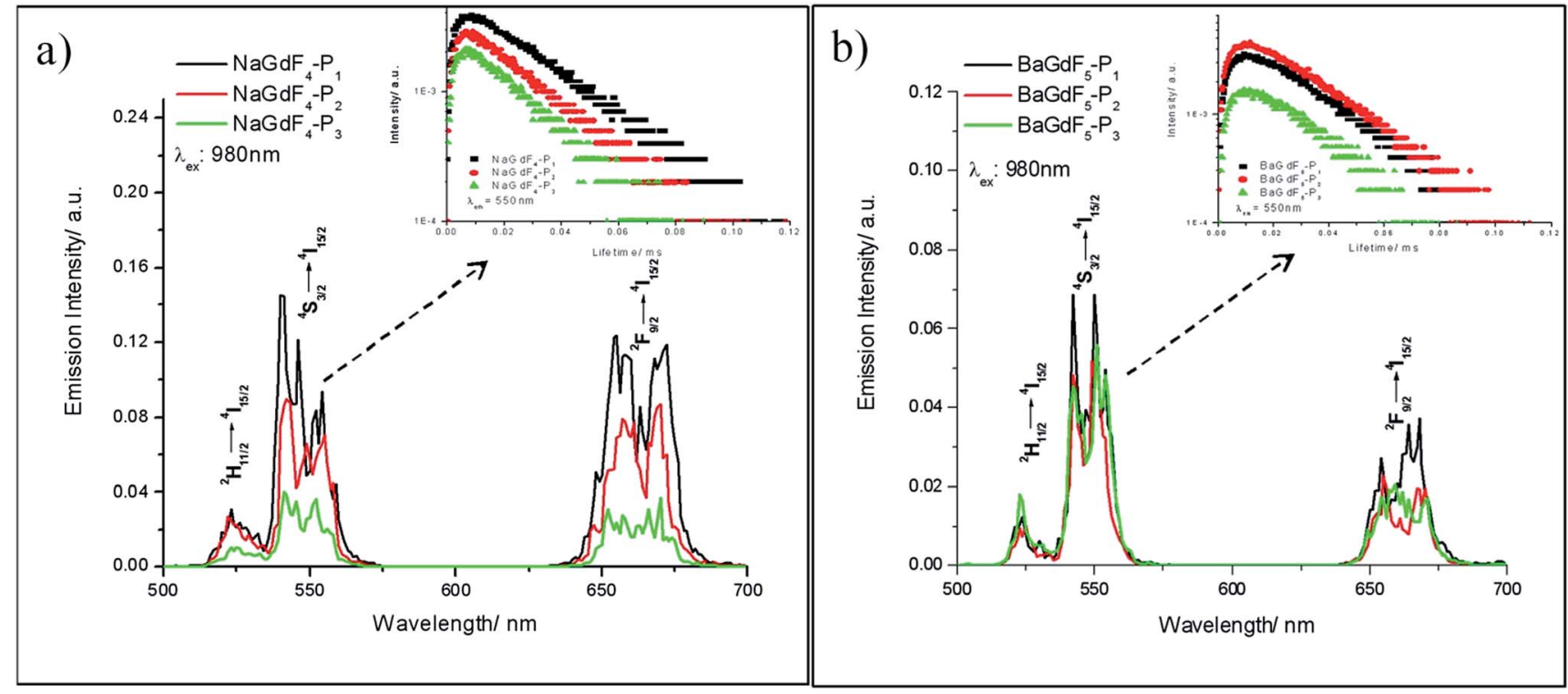

Fig. 4 Upconversion emission spectra of (a) $\mathrm{NaGdF}_{4}-\mathrm{P}_{n}$ and (b) $\mathrm{BaGdF}_{5}-\mathrm{P}_{n}$. The insets are their corresponding lifetimes at $\lambda_{\mathrm{em}}$ : $541 \mathrm{~nm}$. 
excitation could be an ideal material to achieve termination and visualization of cancer cell simultaneously.

\subsection{In vitro cell based assay of UCNPs}

The application of peptides as potential anti-cancer agents is not a new concept; but, there are very limited methods for probing directly the uptake of such peptides in vitro. In our

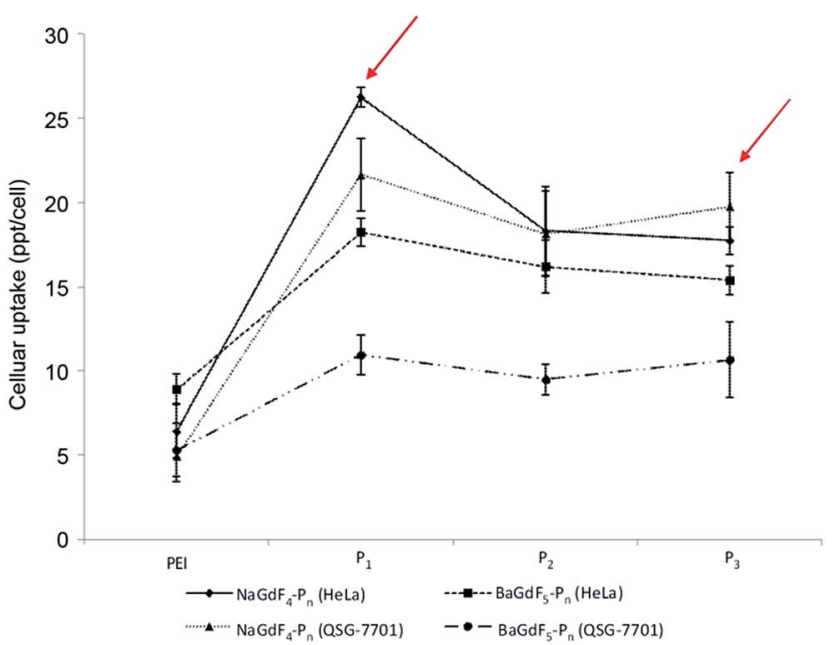

Fig. 5 HeLa and QSG-7701 cellular uptake profile of $\mathrm{NaGdF}_{4}-\mathrm{P}_{n}$ and $\mathrm{BaGdF}_{5}-\mathrm{P}_{n}$ by ICP-MS. The $y$-axis is the cellular uptake concentration at the ppt level per cell.
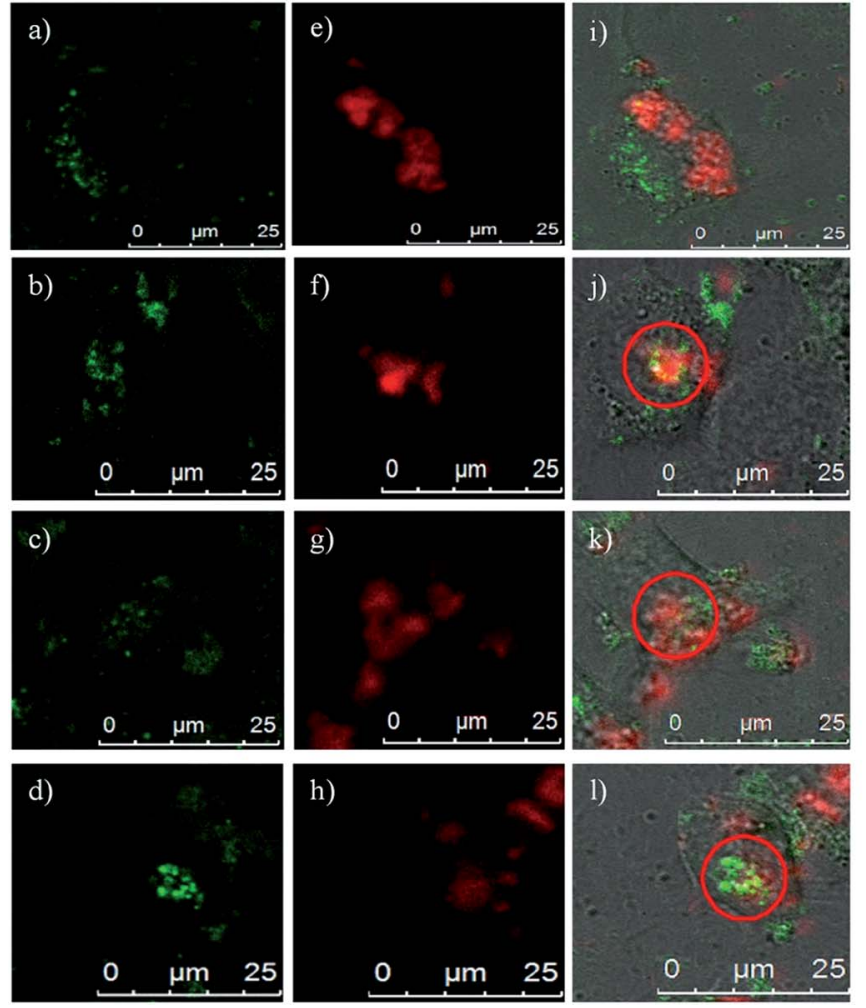

system, the lanthanide content in peptide-functionalized UCNPs offers an in-built and direct monitoring opportunity for ICP-MS evaluation of peptide uptake efficiency in vitro (Fig. 5). From the analysis of the ICP-MS results (Fig. 5), it can be seen that the uptake of two unfunctionalized nanoparticles is similar in both the cancer (HeLa) and the normal (liver derived QSG7701) cells lines. A variation in the uptake rate occurs when the UNCPs are coated with peptides, especially peptides $\mathbf{P}_{\mathbf{1}}$ and $\mathbf{P}_{\mathbf{3}}$ (see arrows in Fig. 5). In fact, in general, there are three main differences between peptide coated and unfunctionalized UCNPs. First, coating with peptides facilitates cell permeability in both cancer (HeLa) and normal (liver derived QSG-7701) cells. Secondly, the $60 \mathrm{~nm} \mathbf{N a G d F}_{\mathbf{4}}-\mathbf{P}_{\boldsymbol{n}}$ shows slightly higher cellular uptake efficiency in comparison with $10 \mathrm{~nm} \mathbf{B a G d F}_{5}-\mathbf{P}_{\boldsymbol{n}}$ in both cancer and normal cell lines. The underlying reason for this could simply be that in the $60 \mathrm{~nm}$ systems a larger surface area is available, and thus more peptides are coated on the nanoparticle. Lastly, peptides $\mathbf{P}_{\mathbf{1}}$ and $\mathbf{P}_{\mathbf{3}}$ helped to improve the selectivity of the uptake, most possibly due to the fact that hydrophilic peptides enhanced the distribution of nanoparticles. In addition, cellular Plk1 may also increase nanoparticle accumulation through specific peptide-protein binding (i.e. greater difference between uptake in cancer versus normal cells). From this later point it also appears that the specific sequence of the peptides, but not their actual length, is important in the binding interactions with Plk1.

m)

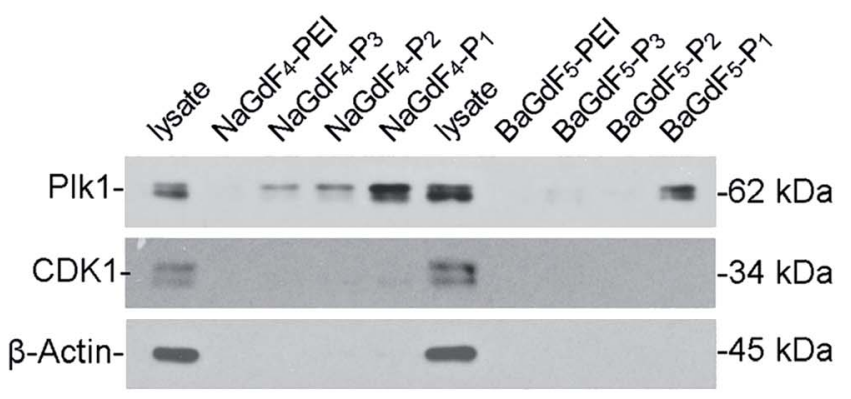

n)

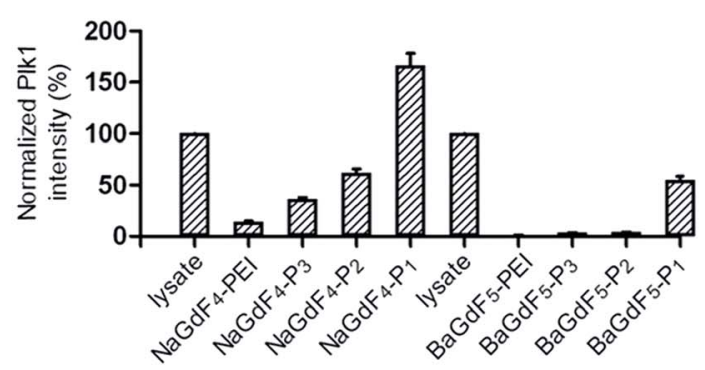

Fig. 6 In vitro images of $(\mathrm{a}-\mathrm{d})$ expressed GFP-Plk1; (e-h) upconversion emission of $\mathrm{NaGdF}_{4}-\mathrm{PEI}_{1}-\mathrm{P}_{1},-\mathrm{P}_{2},-\mathrm{P}_{3}$ respectively and (i-l) their overlay images in HeLa cells. $\left(m\right.$ and $n$ ) The pull down assay compared the binding affinity among $\mathrm{NaGdF}_{4}-\mathrm{P}_{n}$ or $\mathrm{BaGdF}_{5}-\mathrm{P}_{n}$ towards $\mathrm{Plk1}$ and their relative Plk1 intensity respectively. 
Given that our nanomaterials demonstrated interesting photo-physical properties within the biological window, high selectivity for Plk1 (by western blotting), and that they are more readily taken up by cancer cells, the potential of $\mathbf{N a G d F}_{4}-\mathbf{P}_{n}$ or BaGdF $_{5}-\mathbf{P}_{\boldsymbol{n}}$ to act as in vitro imaging bio-probes for Plk1 appeared very promising. To investigate this further, in vitro experiments were conducted in cervical carcinoma HeLa cells with two-photon microscopes (Fig. S3 $†$ ). $\mathbf{N a G d F}_{4}-\mathbf{P}_{\boldsymbol{n}}$ or $\mathbf{B a G d F}_{5^{-}}$ $\mathbf{P}_{\boldsymbol{n}}$ have, as expected, detectable emissions within the biological window $(500 \mathrm{~nm}$ to $700 \mathrm{~nm}$ ) via the near-infrared excitation at $980 \mathrm{~nm}$. Such upconversion inside the cells can also help us to confirm the cell permeability of our UCNPs. The near-infrared (excitation) to near-infrared (emission) in vitro imaging of $\mathbf{N a G d F}_{4}-\mathbf{P}_{n}$ or $\mathbf{B a G d F}_{5}-\mathbf{P}_{\boldsymbol{n}}$ can be correlated with the uptake results in Fig. S3. $\dagger$ Under the NIR excitation by the multi-photon confocal microscope, impressive green $\left({ }^{4} \mathrm{~S}_{3 / 2} \rightarrow{ }^{4} \mathrm{I}_{15 / 2}\right)$ and red (Fig. 6, ${ }^{2} \mathrm{~F}_{9 / 2} \rightarrow{ }^{4} \mathrm{I}_{15 / 2}$ ) f-f emissions can be observed in HeLa cells due to the presence of $\mathbf{N a G d F}_{4}-\mathbf{P}_{\boldsymbol{n}}$ or $\mathbf{B a G d F}_{5}-\mathbf{P}_{\boldsymbol{n}}$ after 24 hours incubation. The in vitro emission spectra were recorded with the lambda scan system on a confocal microscope (resolution $=3 \mathrm{~nm}$ ), the erbium emission bands ${ }^{4} \mathrm{~S}_{3 / 2} \rightarrow{ }^{4} \mathrm{I}_{15 / 2}$ and ${ }^{2} \mathrm{~F}_{9 / 2} \rightarrow{ }^{4} \mathrm{I}_{15 / 2}$ are found which is the same as our measurements with these $\mathbf{U C N P}-\mathbf{P}_{\boldsymbol{n}}$ in aqueous solution. Obviously, the in vitro emission of $60 \mathrm{~nm} \mathrm{NaGdF} \mathbf{N}_{4}-\mathbf{P}_{\boldsymbol{n}}$ is far more intense than the 10 $\mathrm{nm} \mathbf{B a G d F}_{5}-\mathbf{P}_{\boldsymbol{n}}$ in vitro. This observation can be found from the in vitro imaging and its emission spectra. $\mathbf{N a G d F}_{\mathbf{4}}-\mathbf{P}_{\mathbf{1}}$ and $\mathbf{N a G d F}_{4}-\mathbf{P}_{3}$ show impressive red emission inside the cell.

The selectivity of the prepared UCNPs toward Plk1 binding was confirmed by co-staining experiments with GFP-Plk1 specific fluorescent protein. (GFP-Plk1 protein is not available with the excitation at $980 \mathrm{~nm}$ ). The co-staining experiments were carried out with the transient expression of the GFP-Plk1 protein in the cancer cells through plasmid transfection, followed by incubation with the UCNPs for another 24 hours. In Fig. 6a, the red emission from bare $\mathbf{N a G d F}_{4}\left(\lambda_{\text {ex }}=980 \mathrm{~nm}\right)$ is not overlapped with the green emission from the GFP-Plk1 protein $\left(\lambda_{\mathrm{ex}}=488 \mathrm{~nm}\right)$. However, in Fig. $6 \mathrm{~b}$ and d, the red emission from $\mathbf{N a G d F}_{\mathbf{4}}-\mathbf{P}_{\mathbf{1}}$ and $\mathbf{N a G d F}_{\mathbf{4}}-\mathbf{P}_{\mathbf{3}}$ overlapped with the green emission from GFP-Plk1 well (red circle and white arrow in Fig. 6b and d). From in vitro microscopy, the up-conversion spectra showing the uptake behaviours of those nanomaterials are similar to what we found in ICP-MS uptake assays. The up-conversion red emission from $\mathbf{N a G d F}_{\mathbf{4}}-\mathbf{P}_{\mathbf{1}}$ and $\mathbf{N a G d F}_{\mathbf{4}}-\mathbf{P}_{\mathbf{3}}$ can be overlayed with the green GFP emission, further supporting the nano- a) 60

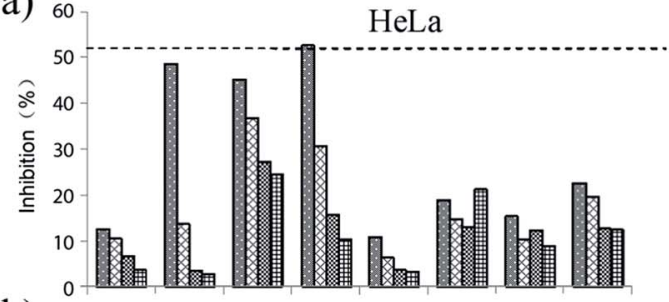

b) 40
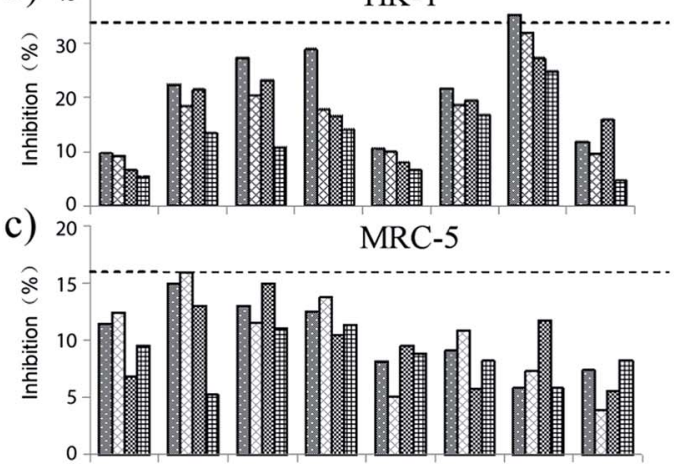

d) 20

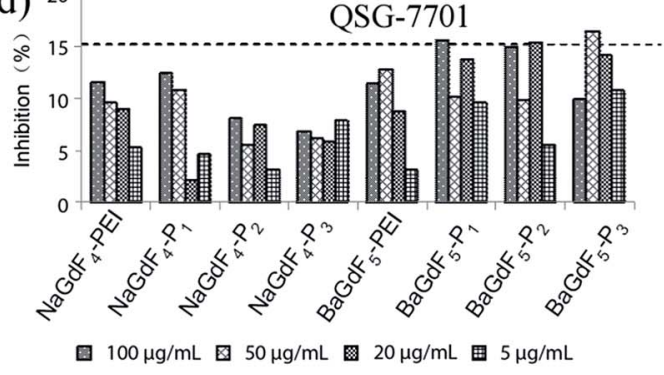

e)
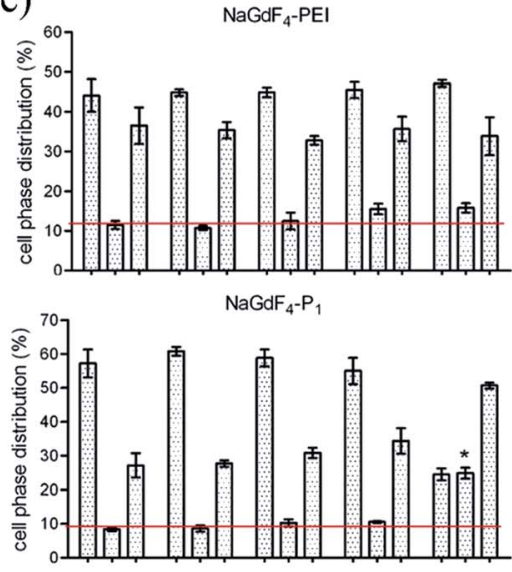

$\mathrm{NaGdF}_{4}-\mathrm{P}_{2}$
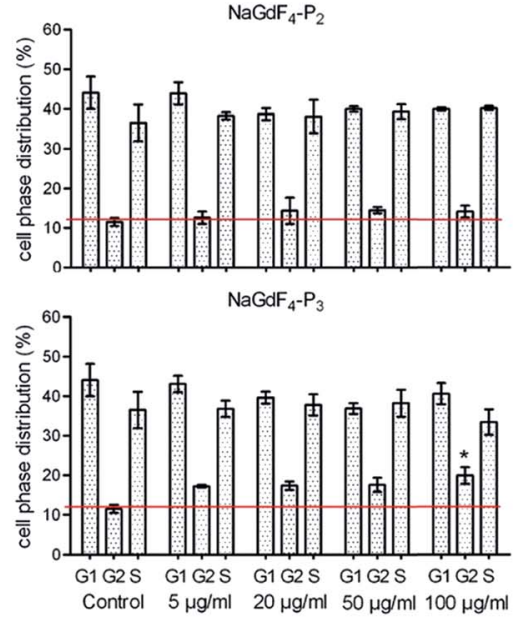

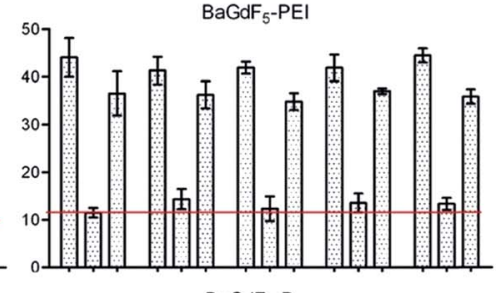

$\mathrm{BaGdF}_{5}-\mathrm{P}_{1}$

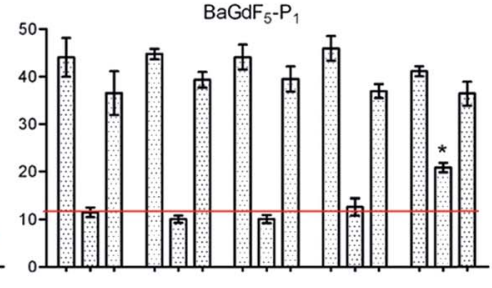

$\mathrm{BaGdF}_{5}-\mathrm{P}_{2}$

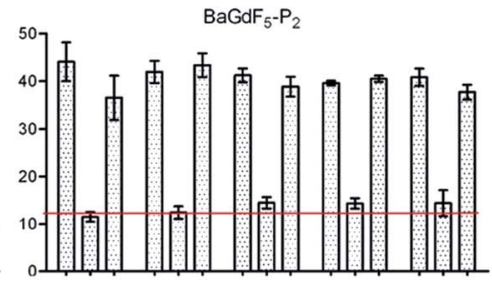

$\mathrm{BaGdF}_{5}-\mathrm{P}_{3}$

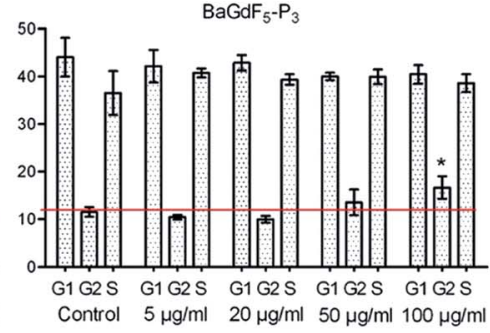

Fig. 7 MTT inhibition assays of $\mathrm{NaGdF}_{4}-\mathrm{P}_{n}$ and $\mathrm{BaGdF}_{5}-\mathrm{P}_{n}$ in (a) human cervical cancer HeLa; (b) human nasopharyngeal carcinoma HK-1; (c) human normal lung fibroblast MRC-5 cell; (d) human liver-derived QSG-7701 cell, and (e) cell cycle interruption in HeLa with flow cytometric analysis. * represents the statistical significance of $P<0.01$. 
material selectivity towards Plk1. In order to further verify the binding selectivity of $\mathbf{N a G d F}_{4}-\mathbf{P}_{\boldsymbol{n}}$ or $\mathbf{B a G d F}_{5}-\mathbf{P}_{\boldsymbol{n}}$ towards Plk1, the nanoparticle-peptide bound Plk1 proteins in the total cell lysate were examined using anti-Plk1 antibodies and western blotting by pull down assay. Among the various $\mathbf{N a G d F}_{4}-\mathbf{P}_{n}$ or $\mathbf{B a G d F}_{5}-\mathbf{P}_{\boldsymbol{n}}$ tested, the $\mathbf{N a G d F}_{\mathbf{4}}-\mathbf{P}_{\mathbf{1}}$ shows the highest binding affinity towards Plk1 (about 10-fold higher) as revealed by the graph of relative Plk1 intensity (Fig. $6 \mathrm{~m}$ and $\mathrm{n}$ ). Therefore, we propose that by conjugating the Plk1 specific peptide $\mathbf{P}_{\mathbf{1}}$ onto the surface, the cellular uptake of our UCNPs should be much higher rather than conjugating other peptides $\left(\mathbf{P}_{2}\right.$ and $\left.\mathbf{P}_{3}\right)$. Hence, $\mathbf{N a G d F}_{\mathbf{4}}-\mathbf{P}_{\mathbf{1}}$ is the best candidate for in vivo imaging nanomaterials compared with the other Plk1 specific peptide analogues.

\subsection{Inhibition of cell viability and cancer cell cycle interruption}

Plk1 expression in different kinds of tumor cells is higher than that in normal healthy cells. Therefore, before further studies and investigation of applications, the inhibitory effect of $\mathbf{N a G d F}_{4}-\mathbf{P}_{\boldsymbol{n}}$ or $\mathbf{B a G d F}_{5}-\mathbf{P}_{\boldsymbol{n}}$ on cancer cells had to be investigated. Firstly, the cell viability was examined using an MTT assay in various cell lines (details are given in the Experimental section). Cell inhibition rates were calculated via viability related absorbance. Fig. 7 shows that $\mathbf{N a G d F}_{\mathbf{4}}-\mathbf{P}_{\boldsymbol{n}}$ or $\mathbf{B a G d F}_{5}-\mathbf{P}_{\boldsymbol{n}}$ exerted a higher inhibitory effect on cell viability, in comparison with the results using $\mathbf{N a G d F}_{4}$-PEI and $\mathbf{B a G d F}_{5}$-PEI in tested cell lines. Among the different Plk1 specific peptides conjugated to the $\mathbf{N a G d F}_{4}-\mathbf{P}_{\boldsymbol{n}}$ or $\mathbf{B a G d F}_{5}-\mathbf{P}_{\boldsymbol{n}}$ systems, $\mathbf{N a G d F}_{4}-$
$\mathbf{P}_{\boldsymbol{n}}$, showed a better inhibitory effect on cancer (HeLa and HK-1) cells in contrast to $\mathbf{B a G d F}_{\mathbf{5}}-\mathbf{P}_{\boldsymbol{n}}$ as highlighted in Fig. 7. The results from the MTT assays carried out in normal cell lines, namely MRC-5 and QSG-7701, demonstrated the selectivity of $\mathbf{N a G d F}_{4}-\mathbf{P}_{\boldsymbol{n}}$ or $\mathbf{B a G d F}_{5}-\mathbf{P}_{\boldsymbol{n}}$ towards cancer cell lines (which overexpress Plk1). In fact, there is a comparable amount of asprepared nanoparticles taken up by HeLa cells and QSG-7701 cells but the inhibitory effect on HeLa is much higher than that on QSG-7701, thereby proving that our $\mathbf{N a G d F}_{\mathbf{4}}-\mathbf{P}_{\boldsymbol{n}}$ or $\mathbf{B a G d F}_{5}-$ $\mathbf{P}_{\boldsymbol{n}}$ can selectively kill cancer cells but remained relatively nontoxic to the normal cells. The $\mathrm{IC}_{50}$ values of $\mathbf{N a G d F}_{\mathbf{4}}-\mathbf{P}_{\boldsymbol{n}}$ or $\mathbf{B a G d F}_{5}-\mathbf{P}_{\boldsymbol{n}}$ are provided in ESI Table S1. $\dagger$ Furthermore, cell cycle interruption was evaluated by flow cytometry. All of the Plk1 specific peptide coated $\mathbf{N a G d F}_{4}-\mathbf{P}_{n}$ or $\mathbf{B a G d F}_{5}-\mathbf{P}_{n}(0-100$ $\mu \mathrm{g} \mathrm{mL}{ }^{-1}$ ) and control ( $\mathbf{N a G d F}_{4}$-PEI or $\mathbf{B a G d F}_{5}$-PEI) had been tested for the inhibitory activity and the data are shown in Fig. 7e. Normally, the cell phase distribution of usual cell division is $\sim 67 \%, \sim 10 \%$ and $\sim 23 \%$ in G1, G2 and $\mathrm{S}$ phases respectively. However, when treated with various $\mathbf{N a G d F}_{\mathbf{4}}-\mathbf{P}_{\boldsymbol{n}}$ or $\mathbf{B a G d F}_{5}-\mathbf{P}_{\boldsymbol{n}}$, only the $\mathbf{N a G d F}_{\mathbf{4}}-\mathbf{P}_{\mathbf{1}}$ showed a significant G2 phase arrest at a dosage concentration of $100 \mu \mathrm{g} \mathrm{mL} \mathrm{m}^{-1}$ (indicated with statistical significance) while other $\mathbf{N a G d F}_{4}-\mathbf{P}_{\boldsymbol{n}}$ or $\mathbf{B a G d F}_{5}-\mathbf{P}_{\boldsymbol{n}}$ showed milder cell cycle interruption.

\subsection{In vivo bio-distribution and mouse xenograft tumor inhibition}

In order to study the metabolism of $\mathbf{N a G d F}_{\mathbf{4}}-\mathbf{P}_{\boldsymbol{n}}$ or $\mathbf{B a G d F}_{5}-\mathbf{P}_{\boldsymbol{n}}$ in an animal model, gadolinium concentration in different mouse tissues was analyzed with ICP-MS. Fig. 8a-c show that $\mathbf{N a G d F}_{\mathbf{4}^{-}}$

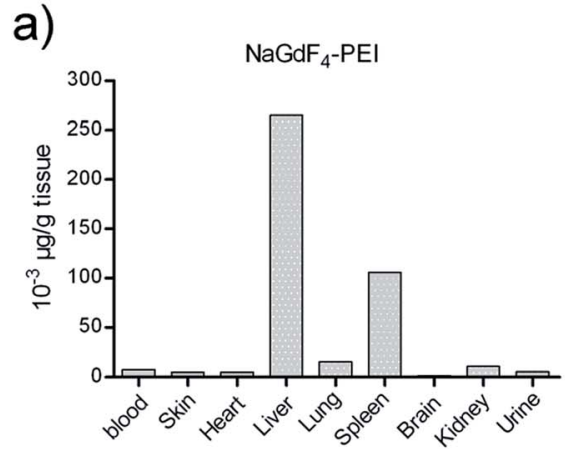

d)

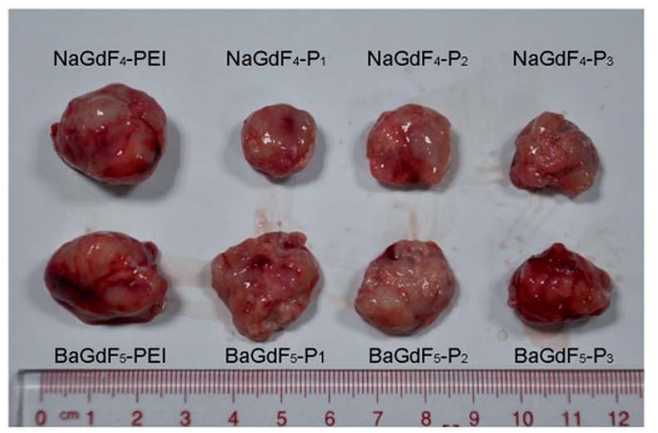

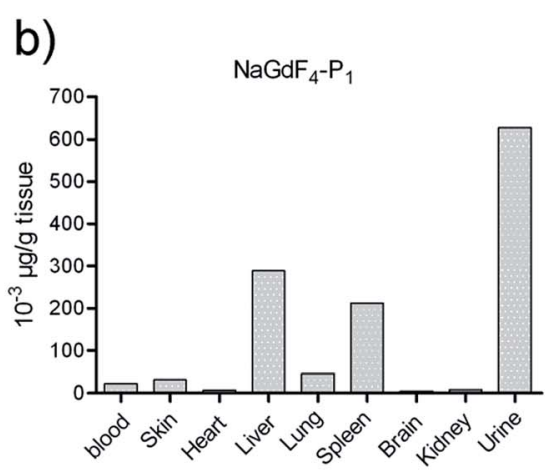

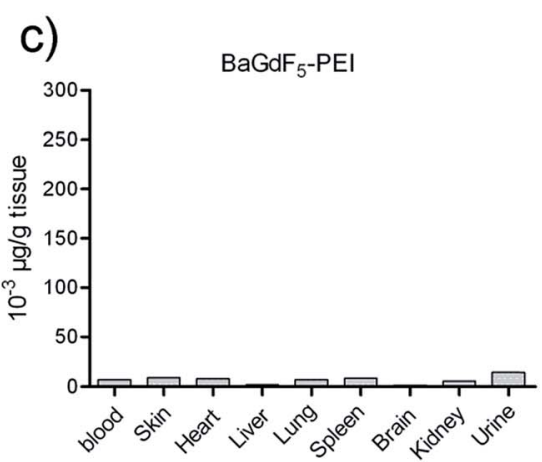

e)

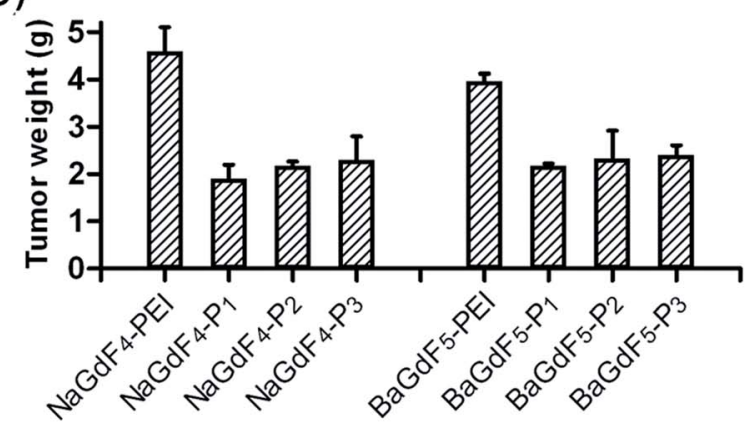

Fig. 8 (a-c) In vivo uptake profiles of $\mathrm{NaGdF}_{4}-\mathrm{PEI}, \mathrm{NaGdF}_{4}-\mathrm{P}_{1}$ and $\mathrm{BaGdF}_{5}-\mathrm{PEl}$ analyzed by ICP-MS respectively. (d) Tumor inhibition effect of $\mathrm{NaGdF}_{4}-\mathrm{P}_{n}$ and $\mathrm{BaGdF}_{5}-\mathrm{P}_{n}$ via subcutaneous injection around the tumor. (e) Xenograft tumor weight after the treatment of $\mathrm{NaGdF}_{4}-\mathrm{P}_{n}$ and $\mathrm{BaGdF}_{5}-\mathrm{P}_{n}$. 
PEI and $\mathbf{N a G d F}_{\mathbf{4}}-\mathbf{P}_{\mathbf{1}}$ accumulate in mice spleen and liver 6 hours after caudal vein injection, while $\mathbf{B a G d F}_{5}$-PEI shows low accumulation in these organs. The reason for this is that $\mathbf{B a G d F}_{5}-\mathbf{P E I}$ was quickly metabolized and excluded. Since liver and spleen are the primary organs responsible for detoxification, our nanomaterials were captured and precipitated in these organs. Interestingly, compared with $\mathbf{N a G d F}_{\mathbf{4}}-\mathbf{P E I}, \mathbf{N a G d F}_{\mathbf{4}}-\mathbf{P}_{\mathbf{1}}$ not only accumulates in the spleen and liver, but it is also excreted in high concentration in the urine which suggests a longer retention time in the body (Fig. 8a and c). In addition, mouse xenograft tumor inhibition was also investigated using our nanomaterials which were subcutaneously injected around the tumor. Fig. 8d clearly shows that treatment with $\mathbf{N a G d F}_{4}-\mathbf{P}_{\boldsymbol{n}}$ (especially $\mathbf{N a G d F}_{\mathbf{4}}-\mathbf{P}_{\mathbf{1}}$ ) results in tumor shrinkage while $\mathbf{B a G d F}_{5}-\mathbf{P}_{\boldsymbol{n}}$ shows only a slight effect on the tumor. Therefore, the tumor inhibition performance of the $\mathbf{N a G d F}_{4}-\mathbf{P}_{\boldsymbol{n}}$ systems was better than that of the $\mathbf{B a G d F}_{4}-\mathbf{P}_{\boldsymbol{n}}$ systems which is completely in line with the results from the in vitro cell line based inhibition studies.

\section{Experimental}

\subsection{Chemicals and materials}

$\mathrm{Ln}\left(\mathrm{NO}_{3}\right)_{3} \cdot 6 \mathrm{H}_{2} \mathrm{O}(\mathrm{Ln}=\mathrm{Gd}, \mathrm{Yb}, \mathrm{Er})$ were purchased from Aldrich and dissolved in de-ionized water (DI-water) to form solutions with concentrations of $0.5 \mathrm{M}$ and $0.1 \mathrm{M}$. Acrylic acid, triisopropylsilane (TIS) and $N$-hydroxy-succinimide (NHS, 98\%) were purchased from Aldrich. Ethylene glycol (EG, 99\%), branched polyethylenimine (PEI, $25 \mathrm{kDa}), \mathrm{BaCl}_{2}(99.99 \%)$ and trifluoroacetic acid (TFA, 99\%) were purchased from Sigma-Aldrich. $\mathrm{NH}_{4} \mathrm{~F}(99.99 \%)$ and $\mathrm{NaCl}(99.99 \%)$ were obtained from Sinopharm Chemical Reagent Co., China., and $N, N^{\prime}$-dicyclohexylcarbodiimide (DCC, 99\%) was purchased from Meyer. 3(Tritylthio)propanoic acid ( $>99 \%)$ was purchased from Dieckmann. All of these chemicals were used as received without further purification.

\subsection{Synthesis of $\mathrm{NaGdF}_{4}$ and $\mathrm{BaGdF}_{5}$ upconversion nanoparticles}

Water-dispersed $\mathbf{N a G d F}_{4}$ was prepared by the one-step hydrothermal method. Typically, $1 \mathrm{mmol}$ of $\mathrm{NaCl}$ and $1 \mathrm{mmol}$ of $\operatorname{Gd}\left(\mathrm{NO}_{3}\right)_{3}(0.5 \mathrm{M}), \mathrm{Yb}\left(\mathrm{NO}_{3}\right)_{3}(0.5 \mathrm{M})$ and $\operatorname{Er}\left(\mathrm{NO}_{3}\right)_{3}(0.1 \mathrm{M})$ with the molar ratio of $78: 20: 2$ were dissolved in $20 \mathrm{~mL}$ of ethylene glycol (EG) and stirred for $30 \mathrm{~min}$. After capping with polyethyleneimine (PEI, branched $25 \mathrm{kDa}$ ), approximately $10 \mathrm{~mL}$ of EG containing 5.5 mmol of $\mathrm{NH}_{4} \mathrm{~F}$ was then added to the above solution and stirred for another $30 \mathrm{~min}$. The obtained mixture was then transferred into a $50 \mathrm{~mL}$ stainless Teflon-lined autoclave, which was sealed and kept at $190{ }^{\circ} \mathrm{C}$ for $24 \mathrm{~h}$. After that, the autoclave was cooled to room temperature naturally and the reaction mixture was separated through centrifugation. Ethanol and DI-water were used to wash the precipitate several times and dried at $70{ }^{\circ} \mathrm{C}$ for $12 \mathrm{~h}$ to obtain the as-prepared samples. As a result, $\mathbf{N a G d F}_{4}$ with PEI as the surface modifier was prepared by the hydrothermal method. The synthesis of $\mathbf{B a G d F}_{5}$ is similar to the above procedure except for replacing $\mathrm{NaCl}$ with $\mathrm{BaCl}_{2}$. The zeta-potential for the $\mathbf{N a G d F}_{4}$ or $\mathbf{B a G d F}_{5}$ colloidal solution was measured to be around $+23.6 \mathrm{mV}$ and $+31.5 \mathrm{mV}$ respectively, indicating the successful conjugation of positively charged PEI on the surface of NPs.

\subsection{Synthesis of Plk1 specific peptides}

The three peptides were obtained by stepwise elongation of the peptide chain by the method outlined below. For peptide $\mathbf{P}_{\mathbf{1}}$, $500 \mathrm{mg}$ of the rink amide resin $\left(0.45 \mathrm{mmol} \mathrm{g}^{-1}\right.$ loading $)$ was suspended in a $20 \%$ solution of piperidine in DMF, stirred for $20 \mathrm{~min}$ at room temperature and washed with DMF prior to subsequent steps. The first amino acid to be coupled, Fmoc-(Bnp)-Thr-OH (420 mg, 4 equiv.), was dissolved in DMF and coupled to the resin in the presence of PyBOP (645 mg, 4 equiv.) and NMM (135 $\mu \mathrm{L}, 4$ equiv.) with the use of microwave chemistry as described previously. ${ }^{15,32}$ Other Fmoc amino acid derivatives, Fmoc-Ser $\left({ }^{t} \mathrm{Bu}\right)-\mathrm{OH}(420 \mathrm{mg}, 4$ equiv.), Fmoc-His(Trt)-OH (438 $\mathrm{mg}, 4$ equiv.), Fmoc-Leu-OH ( $350 \mathrm{mg}, 4$ equiv.), and Fmoc-Pro$\mathrm{OH}(320 \mathrm{mg}, 4$ equiv.), were connected to the resin using an analogous synthetic strategy. Following the final removal of the $\mathrm{N} \alpha$-Fmoc group, the peptide-resin was washed with DMF. The free peptide was obtained by cleavage through the use of $9 \mathrm{~mL}$ of TFA in the presence of $750 \mu \mathrm{L}$ of water and $750 \mu \mathrm{L}$ of TIPS according to the standard procedure. After cleavage, the peptide was purified by preparative reverse phase HPLC. The main peptide-containing fractions were collected and lyophilized. The purity of all final products was confirmed by analytical reverse phase HPLC. $\mathbf{P}_{2}$ and $\mathbf{P}_{3}$ were obtained and purified by the same methodology as the preparation of $\mathbf{P}_{\mathbf{1}}$. $\mathbf{P}_{\mathbf{1}}$ : PLHSpT MALDI-TOF HRMS ([M+1] $\left.]^{+}, m / z\right)$ : calcd for $\mathrm{C}_{24} \mathrm{H}_{42} \mathrm{~N}_{8} \mathrm{O}_{10} \mathrm{P}, 633.27$; found for $[\mathrm{M}+\mathrm{H}]^{+}$, 633.26; $\mathbf{P}_{2}$ : PLHSD MALDI-TOF HRMS $\left([\mathrm{M}+1]^{+}, \mathrm{m} / \mathrm{z}\right)$ : calcd for $\mathrm{C}_{23} \mathrm{H}_{37} \mathrm{~N}_{8} \mathrm{O}_{8}, 568.37$; found for $[\mathrm{M}+\mathrm{H}]^{+}, 568.45$; $\mathbf{P}_{3}$ : GGPLHSPT MALDI-TOF HRMS $\left([\mathrm{M}+1]^{+}, \mathrm{m} / \mathrm{z}\right)$ : calcd for $\mathrm{C}_{28} \mathrm{H}_{47} \mathrm{~N}_{10} \mathrm{O}_{12} \mathrm{P}, 746.31$; found for $[\mathrm{M}+\mathrm{H}]^{+} 747.330$.

\subsection{Bio-conjugation of Plk1 specific peptides onto $\mathrm{NaGdF}_{4}$ or BaGdF $_{5}$}

$50 \mathrm{mg}$ PEI NaGdF 4 nanocrystals were added to $744 \mathrm{mg}$ DCC, 200 $\mathrm{mg}$ acrylic acid and 266 NHS in DMF to react at room temperature overnight. The excess DCC, acrylic acid and NHS were removed by washing with DMF and methanol. The precipitate was then vacuum dried. $30.8 \mathrm{mg}$ DCC, $15.9 \mathrm{mg}$ NHS and $40 \mathrm{mg}$ 3-(tritylthio)propanoic acid were added to $50 \mathrm{mg}$ Plk1 peptide in DMF and stirred at room temperature overnight. Excess DCC, NHS and 3-(tritylthio)propanoic acid were removed by washing with DMF and methanol. The resin of the modified Plk1 peptide was removed by reacting with TFA, TIS and de-ionized water in the ratio of $90: 5: 5$ for 4 hours at room temperature. Finally, the modified $\mathbf{N a G d F}_{4}$ nanocrystal and Plk1 peptide reacted with each other in PBS buffer at $\mathrm{pH} 7.4$ at room temperature overnight. The product was washed with water and methanol three times and vacuum dried overnight. The bioconjugation of Plk1 specific peptides $\left(\mathbf{P}_{\boldsymbol{n}}\right)$ onto $\mathbf{B a G d F}_{5}$ is similar to that onto $\mathbf{N a G d F}_{4}$ except for replacing $\mathbf{N a G d F}_{4}$ with $\mathbf{B a G d F}_{5}$. The characterization of the $\mathbf{N a G d F}_{4}-\mathbf{P}_{n}$ or $\mathbf{B a G d F}_{5}-\mathbf{P}_{n}$ was performed with FTIR transmittance and zeta potential analysis. 


\subsection{Characterization}

Powder X-ray diffraction (XRD) patterns of the as-prepared $\mathbf{N a G d F}_{4}$ or $\mathbf{B a G d F}_{5}$ and $\mathbf{N a G d F}_{4}-\mathbf{P}_{\boldsymbol{n}}$ or $\mathbf{B a G d F}_{5}-\mathbf{P}_{\boldsymbol{n}}$ were recorded using a Rigaku smart lab $9 \mathrm{~kW}$ (Rigaku Japan) with Cu-K $\alpha$ radiation $(\lambda=1.5406 \AA)$. The step scan covered the angular range from $25^{\circ}$ to $60^{\circ}$ in steps of $0.02^{\circ}$. The morphology of the as-prepared samples was characterized by using a Tecnai G2 20 S-TWIN Transmission Electron Microscope operated at $200 \mathrm{kV}$. A fourier transform infrared (FT-IR) spectrometer (Nicolet Avator 630) was used to record the infrared spectra of the samples by using a $\mathrm{KBr}$ pellet technique. The powder materials were pressed into a tungsten mesh grid and installed in situ FT-IR transmittance cell, and the samples were degassed in a vacuum system with a residual pressure of less than $3 \times 10^{-4}$ Torr at room temperature. UC spectra were recorded using an FLS920P Edinburgh analytical instrument apparatus equipped with a $980 \mathrm{~nm}$ diode laser as an UC pump source.

\subsection{Cell culture}

Human nasopharyngeal carcinoma (HK-1) cells and cervical carcinoma (HeLa) cells were cultured in DMEM medium (Gibco) supplemented with 10\% fetal bovine serum (Gibco) and antibiotics (penicillin $50 \mu \mathrm{g} \mathrm{mL} \mathrm{m}^{-1}$; streptomycin $50 \mu \mathrm{g} \mathrm{mL} \mathrm{m}^{-1}$ ). Human liver-derived (QSG-7701) cells were maintained in RPMI 1640 medium supplemented with $10 \%$ fetal bovine serum (FBS) and $1 \%$ penicillin and streptomycin. Human normal lung fibroblast (MRC-5) cells were grown in MEM medium supplemented with $10 \%$ fetal bovine serum (FBS) and 1\% penicillin and streptomycin. All the cells were incubated at $37{ }^{\circ} \mathrm{C}$ in a humidified environment with $5 \% \mathrm{CO}_{2}$.

\subsection{Study of cellular uptake of $\mathrm{NaGdF}_{4}-\mathrm{P}_{n}$ or $\mathrm{BaGdF}_{5}-\mathrm{P}_{n}$ by ICP-MS}

To measure the intracellular concentration of the $\mathbf{N a G d F}_{\mathbf{4}}-\mathbf{P}_{\boldsymbol{n}}$ or BaGdF $_{5}-\mathbf{P}_{n} .1 \times 10^{5}$ cells were plated in each well and incubated with the complex for at $100 \mu \mathrm{g} \mathrm{mL}^{-1}$, which was the same as in vitro imaging. After co-incubation, the cell culture medium containing $\mathbf{N a G d F}_{4}-\mathbf{P}_{\boldsymbol{n}}$ or $\mathbf{B a G d F}_{5}-\mathbf{P}_{\boldsymbol{n}}$ was removed and the exposed cells were further washed with $1 \mathrm{~mL}$ PBS 3 times to remove $\mathbf{N a G d F}_{\mathbf{4}}-\mathbf{P}_{\boldsymbol{n}}$ or $\mathbf{B a G d F}_{5}-\mathbf{P}_{\boldsymbol{n}}$ adhering to the outer cell membrane and the bottom of the confocal dishes. Then the cells were trypsinized and dispersed into $1 \mathrm{~mL}$ of culture medium. The exposed cells were collected by centrifugation at $4000 \mathrm{rpm}$ and the cell pellet was digested in 100 $\mu \mathrm{L}$ of concentrated $\mathrm{HNO}_{3}(69 \%)$ at $70{ }^{\circ} \mathrm{C}$ for 3 hours. The cellular uptake of $\mathbf{N a G d F}_{\mathbf{4}}-\mathbf{P}_{\boldsymbol{n}}$ or $\mathbf{B a G d F}_{5}-\mathbf{P}_{\boldsymbol{n}}$ was determined using an Agilent 7500 series of inductively coupled plasma mass spectroscopy (ICP-MS). All ICP experiments were performed in triplicate and the values obtained were averaged. The concentration of Gd per cell was calculated by determining the concentration of Gd in the cell lysate by ICP-MS and then dividing it by the number of cells which counted using a haematocytometer.

\subsection{In vitro bio-imaging}

To investigate the suitability of the obtained and Plk1 specific peptides coated UCNPs as bio-probes, imaging of HeLa cells $\left(1 \times 10^{5}\right)$ was conducted. After the incubation with $\mathbf{N a G d F}_{\mathbf{4}}-\mathbf{P}_{\boldsymbol{n}}$ or $\mathbf{B a G d F}_{\mathbf{5}}-\mathbf{P}_{\boldsymbol{n}}$ for 24 hours, the cells were washed by PBS 3 times before imaging. The in vitro imaging was performed on a confocal laser scanning microscope, Leica TCS SP5, equipped with a Ti:sapphire laser (Libra II, coherent). The samples were excited by a $980 \mathrm{~nm}$ wavelength laser.

\subsection{Plk1 GFP co-staining in vitro bio-imaging}

To validate the binding between $\mathbf{N a G d F}_{4}-\mathbf{P}_{\boldsymbol{n}}$ or $\mathbf{B a G d F}_{5}-\mathbf{P}_{\boldsymbol{n}}$ and Plk1, GFP co-staining experiment was carried out. Plk1 full length cDNA was PCR amplified from pOTB7-Plk1 and inserted into multiple cloning sites (MCS) of pEGFP-C3 (CLONETECH, \#6082-1) using restriction digestion sites of XhoI/EcoRI for GFPPlk1 expression. The positive recombinant was selected through kanamycin proved by sequencing. Plasmids were purified using a StarPrep Plasmid Miniprep Kit (Genstar). For transfection, a $3.5 \mathrm{~cm}$ dish of HeLa cells (with $70-80 \%$ confluence) was transfected with $8 \mu \mathrm{g}$ DNA using lipofectamine 2000 according to the manufacturer instructions. Then, $500 \mu \mathrm{L}$ of the lipofectamine 2000 and plasmid were added to the confocal dish with $500 \mu \mathrm{L}$ cell medium. After incubation for 8 hours, $100 \mu \mathrm{g} \mathrm{mL}{ }^{-1}$ of $\mathbf{N a G d F}_{4}-\mathbf{P}_{n}$ or $\mathbf{B a G d F}_{5}-\mathbf{P}_{n}$ was added and incubated for 24 hours. The imaging procedures and parameters were the same as given in the previous in vitro bio-imaging section.

\subsection{MTT inhibition rate assay}

$1 \times 10^{5}$ of HK-1, HeLa, QSG-7701 and MRC-5 were treated with $\mathbf{N a G d F}_{4}-\mathbf{P E I}$ or $\mathbf{B a G d F}_{5}-\mathbf{P E I}$ and $\mathbf{N a G d F}_{4}-\mathbf{P}_{\boldsymbol{n}}$ or $\mathbf{B a G d F}_{5}-\mathbf{P}_{\boldsymbol{n}}$ for 24 hours. Then the cells were treated with nanoparticles at 4 concentrations $\left(100 \mu \mathrm{g} \mathrm{mL} L^{-1}, 50 \mu \mathrm{g} \mathrm{mL}^{-1}, 20 \mu \mathrm{g} \mathrm{mL}{ }^{-1}\right.$ and $5 \mu \mathrm{g}$ $\left.\mathrm{mL}^{-1}\right)$. The cell monolayers were rinsed with phosphate buffer saline (PBS) once and incubated with $0.5 \mathrm{mg} \mathrm{mL}^{-1}$ MTT solution. The cellular inhibitory potency of the nanoparticles was examined by the formation of formazan after addition of MTT (3-(4,5-dimethylthiazol-2-yl)-2 and 5-diphenyltetrazolium bromide) for 4 hours to allow formazan production during cell metabolism. After that, formazan was fully dissolved in DMSO through oscillating. Finally, the absorbance of solution was measured with a Biotek Power wave xsMicroplate Reader at a wavelength of $570 \mathrm{~nm}$ and $690 \mathrm{~nm}$.

\subsection{Flow cytometry}

$10^{6}$ cells were harvested by trypsine digestion, washed twice in PBS, and then fixed in $70 \%$ ethanol for 2 hours at $4{ }^{\circ} \mathrm{C}$. After removal of the ethanol, cells were resuspended in PBS and then subjected to PI staining (1\% triton-100, $50 \mu \mathrm{g} \mathrm{mL}{ }^{-1}$ RNase A, 20 $\mu \mathrm{g} \mathrm{mL}{ }^{-1}$ propidium iodide) for 40 minutes at $37^{\circ} \mathrm{C}$. Cell phase distributions were analyzed in BD FACS Calibur and the results were processed by Flowjo 7.6.1, shown as the offset histogram and column.

\subsection{Antibodies and western blotting}

Anti- $\beta$-actin (\#66009-1-Ig) antibodies were purchased from Proteintech Group, Inc. Anti-CDK1 (\#9116) and anti-Plk1 (\#4535) antibodies were from Cell Signaling Technology. HeLa 
cells in a 12 well-plate were treated with nanoparticles $(1,10,50$, $100 \mu \mathrm{g} \mathrm{mL}{ }^{-1}$ each) for 24 hours, and then rinsed in PBS twice after the culture medium was discarded. Direct lysis in $50 \mathrm{mM}$ Tris-HCl, pH 6.8, 1\% SDS, 10\% glycerol and thorough denaturation in a boiling water bath were followed. The supernatant was collected as a clear lysate after centrifugation steps. Equal amounts of total proteins were loaded onto the $10 \%$ nitrocellular membranes, which was followed by western blotting. All the results finally were analyzed using a Gel-Pro analyzer and GraphPad Prism 5 software.

\subsection{Pull down assay}

Five $10 \mathrm{~cm}$ dishes of cells were lysed in RIPA buffer (50 mM Tris $\mathrm{pH}=7.4,150 \mathrm{mM} \mathrm{NaCl}, 1 \% \mathrm{NP}-40$, phenylmethanesulfonyl fluoride (PMSF) $1 \mathrm{mM}$, cocktail protease inhibitors) for 15 minutes on ice, and then centrifuged at $13000 \mathrm{rpm}$ for 20 minutes. The clear supernatant was collected and the total $5 \mathrm{~mL}$ cellular lysate was divided into eight samples that were subjected to incubation with the $\mathbf{N a G d F}_{\mathbf{4}}$ or $\mathbf{B a G d F}_{5}$ nanoparticle series $\left(100 \mu \mathrm{g}\right.$ each) at $4{ }^{\circ} \mathrm{C}$ for 2 hours. Nanoparticle precipitated proteins were collected by short centrifugation and washed with RIPA buffer three times to remove unbound proteins. Finally, the pull-down proteins underwent SDS-PAGE separation followed by antibody detection.

\subsection{Animals and ethics}

$\mathrm{BALB} / \mathrm{c}$ nude mice were provided by Guangdong Medical Laboratory Animal Center, with the licensing number of SCXK2008-0002 approved by Guangdong Science and Technology Department. Mice were kept in the isolated bio-safety facility for specific pathogen-free animals. All animal feeding and experiments were performed according to the Procedures for the Care of Laboratory Animals approved by the Shenzhen Institute of The Hong Kong Polytechnic University (with Use Permit of Experiment Animal license SCXK-2010-0062).

\subsection{Mouse xenograft tumor inhibition and ICP-MS bio- distribution analysis}

For tumor inhibition assays, human HeLa cells were trypsinized, harvested and resuspended in DMEM. $1 \times 10^{6}$ cells in $100 \mu \mathrm{L}$ DMEM were injected s.c. into the flanks of the mice (6 weeks old). After 14 days when the tumors were about $150 \mathrm{~mm}^{3}$, the animals were randomized into groups for experiments. $\mathbf{N a G d F}_{4}$ and $\mathbf{B a G d F}_{5}$ series of nanoparticles of Plk1 (500 $\mu \mathrm{g}$ for a tumor) were injected around the tumors and the mice were kept for another 7 days. Finally, the tumors were extracted and imaged. For ICP-MS bio-distribution analysis, $200 \mu \mathrm{g}$ nanoparticles were i.p. injected into the mice, and the tissues as well as urine after 24 hour post-injection were collected. Tissues were digested with nitric acid and subjected to ICP-MS for measuring the concentrations of Gd.

\section{Conclusions}

Plk1 has emerged as a promising target for the development of new anti-cancer agents. The polo box domain (PBD) of Plk1 provides an excellent target for the development of molecules to inhibit Plk1 activity and as such we have rationally designed multifunctional lanthanide-doped upconversion nanomaterials to exploit this. Specifically our aim was to design novel nanomaterials that could deliver Plk1 specific peptides into cancer cells causing Plk1 inhibition while simultaneously allowing direct NIR imaging and monitoring. $\mathrm{NaGdF}_{4}: \mathrm{Yb}^{3+}, \mathrm{Er}^{3+}$ $\left(\mathbf{N a G d F}_{4}\right)$ and $\mathrm{BaGdF}_{5}: \mathrm{Yb}^{3+}, \mathrm{Er}^{3+}\left(\mathbf{B a G d F}_{5}\right)$ nanoparticles of two different sizes (60 $\mathrm{nm}$ and $10 \mathrm{~nm}$, respectively) were prepared and then conjugated with Plk1 specific peptides $\left(-\mathbf{P}_{\mathbf{1}}=\right.$ PLHSpT, $-\mathbf{P}_{2}=$ PLHSD, and $-\mathbf{P}_{3}=$ GGPLHSpT) to generate novel nanomaterials. Systematic and comparative studies of the nanomaterials prepared were carried out, and structural morphology, phase composition, upconversion photophysical properties, cellular uptake efficiency, cytotoxicity, tumor selectivity, and Plk1 binding affinity and inhibitory potency were also investigated in detail. The experimental results obtained showed that several of the nanomaterials prepared could achieve our original dual-function aim of anti-cancer activity and NIR imaging. Of the novel bio-conjugated nanomaterials investigated in our study, $\mathbf{N a G d F}_{\mathbf{4}}-\mathbf{P}_{\mathbf{1}}$, demonstrated considerable promise as a system for further development. $\mathbf{N a G d F}_{\mathbf{4}}-\mathbf{P}_{\mathbf{1}}$ emerged as the best candidate for Plk1 binding and imaging and it could effectively exert cell cycle G2/M arrest and thus tumor inhibition both in vitro and in vivo. It is also worth noting that $\mathbf{N a G d F}_{\mathbf{4}}-\mathbf{P}_{\mathbf{1}}$ is selective in its mode of action and that no anti-growth effects on the normal cells lines used in this study were observed. In summary, this study represents one of few examples where systems have been developed that are capable of both Plk1 inhibition and simultaneously direct NIR imaging and monitoring of cancer cells.

\section{Acknowledgements}

This work was funded by grants from The Hong Kong Research Grants Council (HKBU 203013), ESPRC, Hong Kong Baptist University, The Hong Kong Polytechnic University and Durham University.

\section{Notes and references}

1 B. T. Martin and K. Strebhardt, Cell Cycle, 2006, 5, 2881.

2 M. A. Van Vugt and R. H. Medema, Oncogene, 2005, 24, 2844.

3 X. Liu, M. Lei and R. L. Erikson, Mol. Cell. Biol., 2006, 26, 2093.

4 B. Vogelstein, N. Papadopoulos, V. E. Velculescu, S. Zhou, L. A. Diaz Jr and K. W. Kinzler, Science, 2013, 339, 1546.

5 S. M. Lens, E. E. Voest and R. H. Medema, Nat. Rev. Cancer, 2010, 10, 825.

6 K. Strebhardt, L. Kneisel, C. Linhart, A. Bernd and R. Kaufmann, J. Am. Med. Assoc., 2000, 283, 479.

7 V. Maire, F. Némati, M. Richardson, A. Vincent-Salomon, B. Tesson, G. Rigaill, E. Gravier, B. Marty-Prouvost, L. De Koning, G. Lang, D. Gentien, A. Dumont, E. Barillot, E. Marangoni, D. Decaudin, S. Roman-Roman, A. Pierré, F. Cruzalegui, S. Depil, G. C. Tucker and T. Dubois, Cancer Res., 2013, 73, 813. 
8 X. Liu and R. L. Erikson, Proc. Natl. Acad. Sci. U. S. A., 2003, 100, 5789.

9 R. Lan, G. Lin, F. Yin, J. Xu, X. Zhang, J. Wang, Y. Wang, J. Gong, Y. Ding, Z. Yang, F. Lu and H. Zhang, Lab. Invest., 2012, 92, 1503.

10 K. V. Gleixner, V. Ferenc, B. Peter, A. Gruze, R. A. Meyer, E. Hadzirjusufovic, S. Cerny-Reiterer, M. Mayerhofer, W. F. Pickl, C. Sillaber and P. Valent, Cancer Res., 2010, 70, 1513.

11 J. Q. Shi, K. Lasky, V. Shinde, B. Stringer, M. G. Qian, D. Liao, R. Liu, D. Driscoll, M. T. Nestor, B. S. Amidon, Y. Rao, M. O. Duffey, M. G. Manfredi, T. J. Vos, N. D'Amore and M. L. Hyer, Mol. Cancer Ther., 2012, 11, 2045.

12 F. Liu, J. E. Park, W. J. Qian, D. Lim, M. Gräber, T. Berg, M. B. Yaffe, K. S. Lee and T. R. Burke Jr, Nat. Chem. Biol., 2011, 9, 595.

13 S. M. Yun, T. Moulaei, D. Lim, J. K. Bang, J. E. Park, S. R. Shenoy, F. Liu, Y. H. Kang, C. Liao, N. K. Soung, S. Lee, D. Y. Yoon, Y. Lim, D. H. Lee, A. Otaka, E. Appella, J. B. McMahon, M. C. Nicklaus, T. R. Burke Jr, M. B. Yaffe, A. Wlodawer and K. S. Lee, Nat. Struct. Mol. Biol., 2009, 16, 876.

14 S. M. Kim, S. Yoon, N. Choi, K. S. Hong, R. N. Murugan, G. Cho and E. K. Ryu, Biomaterials, 2012, 33, 6915.

15 I. R. Ruttekolk, F. Duchardt, R. Fischer, K. H. Wiesmuller, J. Rademann and R. Brock, Bioconjugate Chem., 2008, 10, 2081.

16 J. Yuan, A. Hoerlin, B. Hock, H. J. Stutte, H. W. Ruebsamen and K. Strebhardt, Am. J. Pathol., 1997, 4, 1165.

17 Z. H. Chen, R. J. Zhao, R. H. Li, C. P. Guo and G. J. Zhang, PLoS One, 2013, 8, e53291.

18 H. Li, C. F. Chan, W. L. Chan, S. Lear, S. L. Cobb, N. Mak, T. C. Lau, R. Lan, W. K. Wong and K. L. Wong, Org. Biomol. Chem., 2014, 12, 5876.

19 X. Xie, N. Gao, R. Deng, Q. Sun, Q. H. Xu and X. Liu, J. Am. Chem. Soc., 2013, 34, 12608.
20 Y. F. Wang, G. Y. Liu, L. D. Sun, J. W. Xiao, J. C. Zhou and C. H. Yan, ACS Nano, 2013, 8, 7200.

21 P. Escribano, B. Julian-Lopez, J. Planelles-Arago, E. Cordoncillo, B. Viana and C. Sanchez, J. Mater. Chem., 2008, 18, 23.

22 S. Zeng, M. K. Tsang, C. F. Chan, K. L. Wong and J. Hao, Biomaterials, 2012, 33, 9232.

23 R. Naccache, P. Chevallier, J. Lagueux, Y. Gossuin, S. Laurent, L. Vander Elst, C. Chilian, J. A. Capobianco and M. A. Fortin, Adv. Healthcare Mater., 2013, 2, 1478.

24 N. Bogdan, E. Martín Rodríguez, F. Sanz-Rodríguez, M. C. Iglesias-de la Cruz, A. Juarranz de la Fuente, D. Jaque, J. GarcíaSolé and J. A. Capobianco, Nanoscale, 2012, 4, 3647.

25 Q. Liu, W. Feng, T. Yang, T. Yi and F. Li, Nat. Protoc., 2013, 8, 2033.

26 W. Feng, C. Han and F. Li, Adv. Mater., 2013, 25, 5287.

27 L. D. Carlos, R. A. S. Ferreira, V. Z. Bermudez, B. Julian-Lopez and P. Escribano, Chem. Soc. Rev., 2011, 40, 536.

28 M. L. Debasu, D. Ananias, S. L. C. Pinho, C. F. G. C. Geraldes, L. D. Carlos and J. Rocha, Nanoscale, 2012, 4, 5154.

29 J. Wu, Q. Tian, H. Hu, Q. Xia, Y. Zou, F. Li, T. Yi and C. Huang, Chem. Commun., 2009, 27, 4100.

30 Q. Liu, B. Yin, T. Yang, Y. Yang, Z. Shen, P. Yao and F. Li, J. Am. Chem. Soc., 2013, 13, 5029.

31 S. J. Butler and D. Parker, Chem. Soc. Rev., 2013, 42, 1652.

32 C. F. Chan, M. K. Tsang, H. Li, R. Lan, F. L. Chadbourne, W. L. Chan, G. L. Law, S. L. Cobb, J. Hao, W. T. Wong and K. L. Wong, J. Mater. Chem. B, 2014, 2, 84.

33 P. Loyera, J. H. Trembleya, R. Katonac, V. J. Kidda and J. M. Lahti, Cell. Signalling, 2005, 17, 1033.

34 E. Pretsch, P. Bühlmann and C. Affolter, Structure Determination of Organic Compounds, Springer, Berlin Heidelberg, 2000, p. 250. 